\title{
Determinants for a Feasible Short Sea Shipping: Lessons from Europe for ASEAN
}

\author{
Aminuddin Md Arof ${ }^{1}$ \\ ${ }^{1}$ Universiti Kuala Lumpur, Malaysian Institute of Marine Engineering Technology, Lumut, Malaysia \\ Correspondence: Aminuddin Md Arof, Universiti Kuala Lumpur, Malaysian Institute of Marine Engineering \\ Technology, Pantai Remis Road, Lumut, Malaysia. Tel: 60-13-672-1480. E-mail: aminuddin@unikl.edu.my
}

Received: January 29, 2015 Accepted: March 5, 2015 Online Published: May 15, 2015

doi:10.5539/ass.v11n15p229 URL: http://dx.doi.org/10.5539/ass.v11n15p229

\begin{abstract}
This paper aims to review the key factors for a feasible Short Sea Shipping (SSS) operation that is currently beginning to regain its popularity across the globe through the survey of literature beginning from the year 1999 to 2014. Although the literature has addressed a myriad of important factors through research conducted particularly in Europe, it could be argued that the important determining factors that are required for a particular route or area may not be applicable to another route or area. In Europe, SSS is introduced with the main purpose of diverting freight transportation away from the congested roads whilst for the ASEAN countries, SSS has been part of the initiative to ensure the attainment of a well-connected ASEAN community. Hence, although important lessons could be learned from the European experience, a thorough study would have to be conducted before any SSS endeavour is initiated to ensure the important determining factors for its success are identified. This would enable SSS investors and authorities of countries involved to focus their limited resources to ensure the success of their SSS undertaking.
\end{abstract}

Keywords: Short Sea Shipping (SSS), Association of Southeast Asian Nations (ASEAN), Ro-Ro, Motorways of the Sea (MoS), Philippines Nautical Highway (PNH)

\section{Introduction}

Since the early 1990s Short Sea Shipping (SSS) has regained its dynamism that it has lost to road transportation due to the rapid expansion of highways, bridges and underwater tunnels in the $20^{\text {th }}$ century. However, the uncontrolled growth of road transportation has led to serious traffic congestions at urban centres and choke points, high construction and maintenance cost of road infrastructure, environmental pollution, increasing number of road accidents and higher operational cost. These phenomena have led authorities particularly in Europe to look for an alternative mode of transportation, in which SSS seems to be the leading choice. SSS generally involves the transportation of cargo, passengers and vehicles by ships along the coasts, to and from nearby islands, within internal waters such as lakes and rivers but without crossing an ocean. It encompasses a large variety of maritime transportation activities, including a wide range of vessel types, cargoes, port infrastructures, policies and regulations, as well as opinions and perceptions. Although SSS services have been re-introduced particularly in Europe since the early 1990s, not all the routes share the same success stories in spite of the various assistance and policies provided by the European Commission and national governments. Hence, this paper attempts to review and tabulate the important determinants that have enabled feasible SSS operations in Europe in order to assist future research on SSS particularly in countries of the Association of Southeast Asian Nations (ASEAN).

In light of the re-emergence on the popularity of SSS, many studies have been conducted on this transportation mode as an alternative to road transportation particularly in Europe and North America. Among the notable studies are Baindur and Viegas (2011) that identify critical factors and barriers for establishing a successful European SSS project as well as Medda and Trujillo (2010) that identify the main determinants for SSS success in Europe. In North America, Yonge and Henesey (2005) examine the factors that are important in the development of SSS decision tool. Similarly, Perakis and Denisis (2008) and Kennedy (2008) attempt to identify the prospect of SSS in the United States by highlighting the major inhibitions that must be overcome. In spite of the significant number of studies conducted in Europe and North America, similar studies on SSS in other parts of the world that could be traced through the open literature are still limited. 


\section{Aim}

This paper aims to identify important determinants to enable the introduction of a feasible SSS operation that could be gathered through the open literature from the year 1999 onward based on studies done on European SSS. This is because interstate SSS is arguably much more developed in the European continent compared to the other parts of the world. It is hoped that this effort would assist in the understanding of the complexity of the variables involved in ensuring the success of a SSS endeavour especially in the member countries of Association of Southeast Asian Nations (ASEAN) that are embarking on their own interstate SSS to ensure the achievement of a well-connected ASEAN Economics Community.

\section{Definition of Short Sea Shipping}

In general, there is no strict definition of SSS from the aspects of type of vessel used, distance travel, or type of cargo or passenger transported. In fact, according to Medda and Trujillo (2010), there is still no consensus among experts on the definition of SSS, whilst Douet and Cappuccilli (2011) argue that a concise, unambiguous definition of SSS does not exist. The first definition of SSS can be traced from Balduini (1982) that defines it as "a maritime transport between ports of a nation as well as between a nation's port and the ports of adjacent countries". Subsequently many definitions have emerged using several different criteria such as geographical, involving the voyage length; legal that is limited to cabotage regime; commercial involving competition with other mode of transport, distinction between feeder and intra-regional traffic as well as based on the nature of cargo; and supply involving the type and size of the vessels or investors (Douet \& Cappuccilli, 2011). In spite of the many definitions on SSS that could traced through the literature, the geographic criterion seems to be the most commonly utilised (Douet \& Cappuccilli, 2011). Hence, for the purpose of this research, a general definition of SSS as "the movement of goods and people within coastal waters and inland waterways on routes that do not involve transit through the oceans", will be adopted. In term of types and sizes, Stopford (2009) argues that SSS involved any ships used in transporting cargo and passenger ranging from 400 to 6000 tonnes. Similarly, Paixao and Marlow (2002) summarise that although SSS vessels could range from 100 to 10,000 tonnes, the average deadweight tonnage (DWT) for SSS in Europe can be said to be in the range between 1500 to 2200 tonnes.

\section{Historical Background of Short Sea Shipping}

Prior to the development of extensive rail and road transportation networks in many parts of the world, commercial shipping via inland and coastal waterways was the mode of choice among shippers. Nevertheless, the rapid growth of road and rail transportation since the $20^{\text {th }}$ century led to the decrease in popularity of coastal and inland shipping. It could be argued that due the increased efficiency of road transportation, SSS has been perceived by many as a slow, unreliable and obsolete mode of transportation. Fortunately for shipping operations, the rapid growth of road vehicles in many developed countries including the growth of freight transportation over the last several decades, has led to the increase of road transport inefficiencies due to higher congestion, pollution, road accidents and vehicle operational costs. This phenomenon has led many governments to examine the feasibility of introducing or enhancing an alternative mode of transportation that could accommodate some of the vehicles and divert them away from the roads.

In Europe for instance, the European Commission has begun to recognise SSS as a viable transport mode (European Commission, 1999). SSS is also regarded by the EC as the only freight mode that could offer a realistic prospect of a significant modal shift from road, as well as improve competitiveness and reduce environmental damage; which fundamentally explains the strong emphasis by the EC in developing its Motorways of the Sea (MoS) policy (Medda \& Trujillo, 2010). MoS concept is a special feature of SSS and is defined as "existing or new sea-based transport services that are integrated in door-to-door logistic chains and concentrate flows of freight on viable, regular, frequent, high-quality and reliable Short Sea Shipping link" (European Commission, 2007). The deployment of the MoS is aimed at absorbing a significant part of the expected increase in road freight traffic, improve the accessibility of the peripheral and island regions as well as reduce road congestion (European Commission, 2007). MoS is particularly aimed in forming an alternative to long distance road transport (Baird, 2007). In fact, the EC has actively supported SSS since 1992 through the funding of various projects under its common transport policy (European Commission, 1999). SSS has since, become a fundamental cornerstone of European Union's transport policy. It has been incorporated as a major component of the Marco Polo programmes besides being a part of the Trans-European Networks (TEN-T). The "White Paper on European Transport Policy for 2010" that was drawn in 2001 underscored the significant role that SSS could play in limiting the growth of truck traffic, rebalancing the modal split and avoiding bottlenecks on roads (European Commission, 2001). 
In spite of the satisfactory development of SSS in North America, potential challenges such as shortage of suitable port infrastructure and marine terminal facilities; as well as the North American regulatory regimes may still represent significant obstacles (Transport Canada, 2006). In almost a similar situation in Canada and the United States, the issues affecting the growth of SSS services are the high cost of vessels construction in local shipyard and an excessive tax on foreign-built vessels if they were to be used in the coasting or cabotage trade. In addition, there is also a requirement to use local crew for domestic trades. All the preceding factors have contributed to a significant cost that will be finally borne by the SSS customers (Brooks \& Frost, 2004). Although there have been significant interests in the development of SSS in North America since the early 2000, there are many obstacles particularly on the legislative aspects that must be addressed by the respective governments in order to make SSS a viable alternative to road transportation. Among the issues raised are the Cabotage Policy that has resulted in high capital and high operating costs in the operations of SSS, Harbour Maintenance Tax (HMT) and double insurance requirements for the tug and barge system (Kennedy, 2008). Unless these issues are resolved, it would not be able to encourage private sector investment in the required infrastructures and participation in short sea operations. Hence, it would be difficult for SSS operations in North America to be as rapidly developed as the SSS operations in Europe.

In Asia, the most successful SSS undertaking could arguably be traced in Japan. Japan is described as the nation that utilises SSS comprehensively all around the country from the north to the south in $3000 \mathrm{~km}$ range. The network involves 48 operators, 23 routes, 101 vessels and 112 ports. It also involves 196 sailings per week with the majority of the vessels employed are Ro-Ro ships, passengers ferry and conventional boats (APEC Transportation Working Group, 2007). In fact, long distance ferry services of more than $300 \mathrm{~km}$ have been the norm in Japan since the late 1960s (Baird, 2007). Most of the ports that are visited by the SSS are relatively smaller ports. However, some routes involved bigger ones like the Port of Tokyo. As a result, shippers who produce high technological goods in certain regions could benefit by the network without suffering from the expensive transportation cost that could occur if road transportation was used between those regions. Similarly, shippers who produce agricultural and fisheries products in less populated localities can greatly benefit from the network to reach markets in metropolitan area over long distance (APEC Transportation Working Group, 2007). Although Japan is geographically considered as a group of islands, domestic coastal ferry services compete directly against long-distance road haulage trucks, as the national expressway system is comprehensive with all four main islands in Japan connected by fixed links (Baird, 2007) (Baindur \& Viegas, 2012). Many of Japanese coastal Ro-Ro services have been enhanced over the years with higher speed vessels of between $24-30$ knots as compared to the older vessels of less than 22 knots (Baird, 2007). This service enhancement has not only made Ro-Ro more attractive and competitive relative to road transportation but has also enabled SSS companies to reduce the number of the fleet while maintaining the same frequency of service (Baird, 2007).

Correspondingly, in Southeast Asia, the Philippines model of nautical highways introduced in 2003 has resulted in seamless connectivity from north to south across the sea and islands and the implementation of Ro-Ro policy. This has led to faster delivery lead time to 3 days down from an average of 9 days and reduced logistics costs (Asian Development Bank, 2010). As a result, there has been rapid growth in cargo volumes on the Ro-Ro network. For instance, on the Western Nautical Highway, rolling cargo traffic has experienced an increase from 254,029 rolling cargoes to 419,740 vehicles in 2008 (Asian Development Bank, 2010). There has also been a significant increase in passenger traffic on the Ro-Ro network. For example, passenger volumes on the Western Nautical Highway increased from 1.86 million in 2003 to 3 million in 2008 (Asian Development Bank, 2010). The Philippines Nautical Highway model is in fact seen as having great potential for other archipelagic Southeast Asian countries involving Brunei Darussalam, Indonesia, Malaysia, Singapore and Timor Leste as well as the other ASEAN countries (Asian Development Bank, 2010) (Arof, 2013).

\section{Determinants for a Successful SSS Endeavour}

\subsection{The European Experience}

Paixao \& Marlow (2001) presented among the first analysis of SSS as an alternative mode of transportation in Europe. In evaluating the strengths and weaknesses of SSS, they discovered that the weaknesses are mostly related to the port performance and the service quality that SSS could provide. They have also identified the barriers to SSS expansion that involved the lack of efficient port operations, unreliable vessel schedules, and excessive paperwork leading to high administrative costs. However, they have also identified the advantages of SSS such as its ability to achieve economies of scale, environmental benefits, low energy consumption and the lower costs needed for infrastructure expansion (Paixao \& Marlow, 2001). In 2005, the same authors published their article on the competitiveness of SSS (Paixao-Casaca \& Marlow, 2005). In this study, they examined the competitiveness of SSS vis-à-vis the other transportation modes from the aspects of the level of service that SSS 
provides to its customers. The analysis of the feedback received from 46 out of 332 industry participants identified, revealed that the quality of service provided by SSS service providers and the image of SSS relative to other transportation modes are low and poor. Subsequently, Paixao-Casaca and Marlow (2007) divide the SSS market into three segments, namely the pure intra-European trade, the feeder market and the cabotage market, which is a pure domestic trade and trade with islands. They argue that, the economic viability of the SSS operation is dependent on the right mix of ship type, cargo to be carried and speed because as the speed increases, the fuel consumption would grow more rapidly (Paixao-Casaca \& Marlow, 2007).

Musso and Marchese (2002) look at the competitiveness of SSS by examining its different markets and its advantages and disadvantages. These conditions describe the critical thresholds for the optimal trip distances and the corresponding costs that could enable SSS to be more competitive than the other modes of transportation. Even though it appears as a simple methodology, the relationship between transportation costs and trip distances could be considered as interesting. The authors considered that SSS competitiveness depends directly on the sea-leg distances with the average distance for SSS in Europe as $1,385 \mathrm{~km}$ compared to $100 \mathrm{~km}$ for road transport (Musso \& Marchese, 2002). They also proposed that both internal and external costs, such as environmental and social costs, should be included as the actual cost of transportation. In looking at intra Great Britain coastal shipping in a multi-modal chain, four important determining factors have been identified as imperatives for the success of the domestic SSS operation i.e. competitiveness of shipping companies, inter-modalism involving integration into the supply chain, marketing and ports competitiveness (Saldanha \& Gray, 2002). A two-round Delphi survey conducted on 11 expert panels comprising of the management of shipping and related companies have discovered a strong emphasised on inter-modalism with $83.2 \%$ consensus among experts. This is followed by Marketing (75.6\%), Port Efficiency (69\%) and Competitiveness of shipping companies with $68.9 \%$ consensus (Saldanha \& Gray, 2002).

Looking from the supply chain point of view, SSS is one of the modes to transport goods from one port to another. Generally these ports are neither the points of origin nor the points of destination for the freight. Hence, if SSS is to be used, the goods involved should be moved mostly by trucks from the point of origin to the loading point and from the point of discharge to the point of destination (Becker, Burgess, \& Henstra, 2004). As a result, the qualities in the reliability of delivery, capacity and high service frequency would be expected from the transport chain where shippers and forwarders would select the transport mode on the basis of total logistics costs and the urgency of delivery (Becker et al., 2004). In this regard, it has been argued that the requirement for a high speed vessel, i.e. ships with a speed higher than a conventional vessel, that is $>23$ knots for the European environment is not critical for the movement of cargo (Becker et al., 2004). Through their analysis, Becker et al. (2004) discover that investment in cargo handling in European ports may yield a much higher return than investment in ship propulsion for higher speed. This is because reduction of the port time could result in a double effect on the total transport time compared to the same reduction in sea time (Becker et al., 2004). In the supply chain perspective, it has been argued that (i) intensive promotion of SSS, (ii) growth of cargo volume, (iii) level of cooperation between parties active in port, (iv) efficient and effective multi-modal network, and (v) standardisation of port infrastructure and port interfaces are the important determining factors for a successful SSS network in Europe (Becker et al., 2004).

Similarly, Grosso et al. (2008) through their survey among Italian Ro-Ro SSS operators and freight forwarders, discovered that competitiveness in the market is the most important element affecting the final price of the forwarding service. It was also identified that the two most important costs in the operations of SSS are fuel costs and charter rate or ownership cost (Grosso, Lynce, Silla, \& Vaggelas, 2008). In spite of the domination by both liquid and dry bulk cargo, a study conducted on the competitiveness of SSS in combination with trucks in transporting containerised cargo vis-à-vis long distance road hauliers found that the combination of SSS and trucks to be more competitive when SSS occupies a higher percentage of the route and cargo is moved within coastal or their surrounding regions $(\mathrm{Ng}, 2009)$. Through a simulation on the transportation of containers in Northern Europe on four different routes using container vessels, it was proposed that road haulage is competitive until a distance of $1100 \mathrm{~km}$ whilst SSS will be competitive from $1100 \mathrm{~km}$ until about $2500 \mathrm{~km}(\mathrm{Ng}$, 2009). Another study on modal transport choice among four sectors in Spain i.e. the agroindustry, ceramic tiles, motor vehicle parts and household appliances, discovered that those industries situated within $150 \mathrm{~km}$ distance from the incoming or outgoing seaports were found to have a relative inclination towards using SSS, compared to those situated more than $150 \mathrm{~km}$ away (García-Menéndez \& Feo-Valero, 2009). Similar study also discovered that an intermodal maritime alternative has a relative competitive advantage over integral road transport in shipments involving distance of more than 1500 km (García-Menéndez \& Feo-Valero, 2009). 
Medda and Trujillo (2010) argue that SSS is competitive for certain type of distance, product and with certain types of ships in relation to the time taken to total door-to-door travel. Similarly, Trujillo et al. argue that SSS acts both as a substitute and a complement of other transport modes such as road or rail services. Nevertheless, SSS would be a competitor when it is offered as alternative transport services in a similar route already served by road transport, conventional rail services or even air transport services (Trujillo, Medda \& Gonzalez, 2011). Based on their assessment of the various definitions of SSS, they synthesise two important elements in SSS discussions namely their inter-modality based on efficient nodes and efficient ports, as well as the environmental role of SSS within the chain of freight movement (Trujillo et al., 2011). The main drawbacks of SSS as identified by Trujillo et al. (2011) are related to frequency of services, insufficient integration with other transport modes, difficulty in meeting "just-in-time" requirements, and non-competitive process. They argue that SSS also suffers from perception problem and as a result, is very slow to gain acceptance by shippers because of their unawareness of the full range of available services. For them, SSS is not always a viable option and the applicability of SSS depends on each case because each corridor has its own peculiarities (Trujillo et. al., 2011).

In spite of the success stories, Baindur \& Viegas (2011) have identified the barriers to the success of SSS and Motorways of the Sea (MoS) concept and have grouped them into four categories namely regulatory, technical, commercial and environmental. Regulatory barriers originate from laws issued by authorities concerning pollution, safety and security considerations where the lack of uniformity in methods, standards and effectiveness of inspection measures employed among ports and across the various facilities within a port has resulted in increased administrative burden and costs on carriers. Technical barriers seem to focus more on the differences of the freight distribution system involving Euro-pallets and ISO containers. Commercial barriers deal with the high investment cost of new Ro-Ro ships that dissuade many companies from entering the SSS business unless there is adequate and sustain demand. Finally environmental barriers address the issue of high dependency of maritime transport to weather and climate condition compared to other modes of transportation (Baindur \& Viegas, 2011).

In contrast, although the distance of SSS route from Helsinki to Tallinn is only around $80 \mathrm{~km}$ and is much less than the European average distance of $1385 \mathrm{~km}$, SSS services along this route has prospered since 2004 when Estonia became a member of the European Union (Tapaninen, Sundberg, \& Posti, 2012). Besides a longer alternative route on land, the success of SSS along this route has been contributed by the implementation of a Ropax concept where cargo and passengers are transported in the same vessel to enable an economically profitable solution. This concept was supported by the high amount of traffic of 118,800 trucks and 7 million passengers in 2010 in spite of both Finland and Estonia only having a population of 5.5 million and 1.3 million respectively (Tapaninen et al., 2012). In his study on Ro-Ro SSS in the South Baltic Sea, Wonexius (2012) argues that in designing or employing Ro-Ro SSS, the decisions made by the transport operator must be subjected to trade-offs ranging from platform with specialisation versus flexibility to other technical and operational trade-offs that would have implications to transport accessibility, time and price. It was discovered that all the 28 Ro-Ro ferries operated in the South Baltic have almost similar sizes but the ferry lines decide the trade-offs between ro-ro decks involving the truck, car and rail metres and the passenger compartments differently (Woxenius, 2012). In a case study on Swedish Orient Line (SOL), it was discovered that their decision to cruise at 14 knots on their 20000 GT vessels involved the consumption of only 1.25 tons of fuel/hour vis-à-vis a normal cruising of 18-20 knots of their competitors that consumed an average of 2.3 tons/hour (Woxenius, 2012). The speed versus fuel consumption trade-off may be effective onboard Ro-Ro vessels that focus on the transportation of freight. This is because many stated preference analyses have shown that forwarders prefer precision over short transport time (Woxenius, 2012).

Similarly, Sambracos \& Maniati (2012) in their study involving a comparison between SSS and road freight transport in Greece discovered that the externalities of sea transport are considerably lower compared to road transport. Their findings indicate that accident costs account only for road freight transport, whilst SSS shows savings of $41.63 \%, 60.13 \%$ and $6.78 \%$ in the case of air pollution, $\mathrm{CO} 2$ emissions and nature/landscape respectively. Similarly Suarez-Aleman et al. (2014) argue that the time spend by SSS in port is a major issue as compared to deep sea shipping, where difference in port time may not be as relevant. They propose that in order to enhance port efficiency in SSS operation, time spent in port should be included as another important output beside the amount of cargo moved; passengers boarding and disembarking; and movement of vehicles on and off the SSS and Customs, Immigration, Quarantine and Security (CIQS) efficiency (Suarez-Aleman, Trujillo, \& Cullinane, 2014). 


\subsection{Discussion on the Important Determinants}

In retrospect, Paixao-Casaca and Marlow (2001) (2005) have identified weaknesses in port services, poor service quality of SSS, excessive paperwork, high administrative cost and poor image of SSS among prospective users as potential barriers for the success of a SSS undertaking. Hence, in order to overcome those barriers the important determining factors that should be ensured are port efficiency, provision of a reliable and quality SSS service, implementing a simplified and standardised documentation, as well as serious marketing efforts by the operators and relevant authorities in promoting SSS as a green alternative mode of transportation. In addition, Paixao-Casaca \& Marlow (2007) have also emphasised on the importance of having the right mix of ship type, payload and speed to ensure the economic viability of a SSS operation. Similarly, Medda \& Trujillo (2010) also emphasise on the right mix of ship type, payload and distance travelled. In their analysis, the main drawbacks of SSS are poor frequency of services, insufficient integration with other modes, inefficient nodes and port services, non-competitive process and poor image (Trujillo et al., 2011). In overcoming those disadvantages, other important determining factors for a successful SSS operation would invariably be the provision of a reliable and high frequency SSS schedule, intermodal integration with land transport, a simplified and standardised documentation and embarking on an intensive SSS promotion efforts.

On the other hand, Musso \& Marchese (2002) argue that SSS competitiveness depends directly on the sea-leg distance with the average distance for a SSS route in Europe of about $1385 \mathrm{~km}$. Their study is sanctioned by $\mathrm{Ng}$ (2009) that discovered in his study that SSS is Europe is competitive from a distance of 1,100 to 2,500 km. Similarly, in their study on modal transport choice in Spain, Garcia-Menendez \& Feo-Valero (2009) have also discovered that intermodal maritime alternative will have a relative advantage over land transportation when the shipment distance is more than $1,500 \mathrm{~km}$. Likewise, an Italian study concludes that SSS will be competitive when the sea-leg for cargo movement is longer than the movement on road and when the cargo is moved within the coastal region (Grosso et al., 2008). Nevertheless, the distance requirement stipulated in the preceding studies was not applicable in SSS operation between Helsinki to Talinn with a distance of around $80 \mathrm{~km}$ that thrived due to a longer alternative route on land (Tapaninen et al., 2012).

In an almost similar outcome with Trujillo et al. (2011), the determining factors envisaged by Saldanha \& Gray (2002) in their study on British intra-state SSS are inter-modalism, marketing, port efficiency and competitiveness of shipping companies. The outcome of their survey indicated that the ability of ship owners to be integrated or work closely with land transport owners in an intermodal transport environment is the most important imperative for the success of a SSS endeavour (Saldanha \& Gray, 2002). Similarly, Becker et al. (2004) emphasise on the importance of transport integration in an intermodal environment to ensure the reliability of delivery, capacity and high service frequency. They discovered that investment in cargo handling facilities to improve port efficiency may yield higher return than investing in higher vessel's speed. In addition, it is also important to standardise port infrastructure and port interfaces as well as to engage in an active promotion of SSS (Becker et al., 2004). In order to overcome the barriers postulated by Baindur \& Viegas (2011), it is imperative for the national authorities involved in the joint operation of SSS to harmonise their rules and regulations between ports particularly those involving CIQS. Similarly, the standardisation of the freight distribution system should be seen as an imperative particularly those involving lift-on lift-off (Lo-Lo) operations whilst government assistance in the acquisition of Ro-Ro vessels or during the initial period of operations is necessary in order to entice operators to invest in SSS operations (Baindur \& Viegas, 2011).

Expounding further on the determinant postulated by Paixao-Casaca \& Marlow (2007) and Medda \& Trujillo (2010) involving the right mix of ship type, cargo and space, it has been argued that the introduction of a Ropax concept would enable an economically profitable solution (Tapaninem et al., 2012). Similarly, in his study on Ro-Ro SSS in the South Baltic Sea, Wonexius (2012) discovered that all the ferries operated there have almost similar sizes but the trade-offs involving truck, car and rail metres against passengers compartments was decided differently on different routes. Comparable to Becker et al. (2004), Wonexius (2012) also argues against high speed cruising as his study indicated that freight forwarders prefer precision in schedule over short cruising time. Likewise, Suarez-Aleman et al. (2014) argue that improving port efficiency is more relevant in SSS rather than deep-sea shipping operation. Hence, it can be argued that the reduction in ship's turn-around time in port could reduce the total time of freight movement and mitigate the slow speed of SSS. The summary of the important determinants in ensuring the success of a SSS endeavour through studies conducted on European SSS operations is presented at Table 1 below: 
Table 1. Determinants for a successful SSS operation

\begin{tabular}{|c|c|c|c|c|c|c|c|c|c|c|c|}
\hline Determinants & $\begin{array}{l}\text { Baindur } \\
\quad \& \\
\text { Viegas } \\
(2011)\end{array}$ & $\begin{array}{l}\text { Becker } \\
\text { et al. } \\
(2004)\end{array}$ & $\begin{array}{l}\text { Grosso } \\
\text { et al. } \\
\text { (2008) }\end{array}$ & $\begin{array}{l}\text { Medda } \\
\quad \& \\
\text { Trujillo } \\
\text { (2010) }\end{array}$ & $\begin{array}{c}\text { Musso \& } \\
\text { Marchese } \\
\text { (2002) }\end{array}$ & $\begin{array}{c}\mathrm{Ng} \\
(2009)\end{array}$ & $\begin{array}{c}\text { Paixao-Casaca } \\
\& \text { Marlow } \\
(2001,2005 \\
\text { 2007) }\end{array}$ & $\begin{array}{c}\text { Tapaninen } \\
\text { et al. } \\
\text { (2012) }\end{array}$ & $\begin{array}{l}\text { Trujillo } \\
\text { et al. } \\
(2011)\end{array}$ & $\begin{array}{c}\text { Saldanha } \\
\text { \& Gray } \\
\text { (2002) }\end{array}$ & $\begin{array}{c}\text { Wonexius } \\
\text { (2012) }\end{array}$ \\
\hline $\begin{array}{c}\text { Competitiveness } \\
\text { of shipping } \\
\text { companies }\end{array}$ & & & & & & & & & & $*$ & \\
\hline $\begin{array}{l}\text { Good intermodal } \\
\text { link }\end{array}$ & & * & & & & & & & & * & \\
\hline $\begin{array}{l}\text { Government } \\
\text { assistance at } \\
\text { initial period }\end{array}$ & $*$ & & & & & & & & $*$ & & \\
\hline Port Efficiency & & $*$ & & & & & $*$ & & * & * & \\
\hline $\begin{array}{l}\text { Promotion of } \\
\text { SSS }\end{array}$ & & & & & & & * & & * & * & \\
\hline $\begin{array}{c}\text { Reliable SSS } \\
\text { service with } \\
\text { sufficient } \\
\text { frequency }\end{array}$ & & $*$ & & & & & * & & * & & * \\
\hline $\begin{array}{c}\text { Right mix of ship } \\
\text { type, payload \& } \\
\text { space }\end{array}$ & & & & $*$ & & & * & * & & & * \\
\hline $\begin{array}{c}\text { Simplified \& } \\
\text { standardised } \\
\text { procedures }\end{array}$ & $*$ & & & & & & * & & * & & \\
\hline $\begin{array}{c}\text { Standardised } \\
\text { freight } \\
\text { distribution } \\
\text { system }\end{array}$ & * & & & & & & & & & & \\
\hline $\begin{array}{c}\text { Standardised } \\
\text { port } \\
\text { infrastructure \& } \\
\text { interfaces }\end{array}$ & & * & & & & & & & & & \\
\hline $\begin{array}{c}\text { Suitable sea-leg } \\
\text { distance }\end{array}$ & & & * & & * & * & & & & & \\
\hline
\end{tabular}

\subsection{Implication for ASEAN Countries}

Gleaning from Table 1 above, it can be noticed that the determinants that were frequently identified in European SSS studies are (1) port efficiency, (2) reliable SSS service with sufficient frequency and (3) the right mix of ship type, payload and space. Those factors could also be applicable to the ASEAN environment to ensure the operation of a feasible SSS in the sub-region. Nevertheless, since individual routes or areas may have their own peculiarities, a thorough study would be required to ensure the main determinants that may influence the success of their SSS endeavour are identified. Notwithstanding the preceding argument, due to the archipelagic and coastal nature of the ASEAN region, most of the routes identified would involve connections between the main land and an island or involving an inter-island link where no other suitable alternative mode of transportation especially for freight movement is available (Arof, 2013). Hence, the required sea-leg distance as espoused in three of the European studies may not be applicable in the ASEAN context. On the contrary, simplified and standardised cross-border and shipping procedures may be seen as a more important determinant for ASEAN as compared to the European Union. Indeed, inefficient and lengthy cross border procedures, which add unnecessary frictions and costs to transport operators and consumers have been recognised by the governments 
of ASEAN as a serious challenge that must be addressed in order to achieve the aspired ASEAN community (ASEAN, 2011). This recognition has been supported by the initial finding from a survey among 11 expert respondents from Malaysia and the Philippines on the important determinants to ensure the success of inter-state Ro-Ro SSS undertaking in archipelagic Southeast Asia. In the study, it was discovered that five out of 12 factors that have been shortlisted are considered as very important. In order of importance, the determinants are (1) adequate port facilities and equipment; (2) harmonisation of administrative procedures among ports; (3) suitable ship type in relation to payload, distance and speed; (4) good intermodal links; and (5) government assistance at initial period (Arof \& Nair, 2014). ASEAN has in fact designated 47 ports as the main ports in the trans-ASEAN SSS network (ASEAN, 2011). The prospect of a feasible SSS as part of ASEAN single shipping market seems feasible looking at the significant increase in intra-ASEAN trade in recent years amounting to USD 609 billion in 2013 amounting to $24.2 \%$ of total ASEAN trade compared to USD 458 billion five years earlier (ASEAN, 2014).

\section{Conclusion}

In conclusion, the argument put forth by Trujillo et al. (2011) that the SSS operation for each route or area would have its peculiarity have been supported by the literature review on studies that have been conducted on European SSS itself. Based on the determining factors presented at Table 1, studies conducted could not agree on the exact variables that could be generalised as the main determinants to ensure a success SSS endeavour in every part of the world. In spite of the review conducted, it has to be recognised that the European Union became the proponent of SSS because it was seen as a transport mode that could offer a realistic prospect of substantial modal shift from the congested roads and to reduce environmental damage. On the contrary, the interstate SSS initiative to be introduced between the ASEAN countries is meant to enhance connectivity in the process of building a well-connected ASEAN community where most of the routes identified would not be in direct competition with road transportation. Notwithstanding the preceding statement, the European experience has also demonstrated on the importance of ship operators to ensure that the sea-link is well integrated into the intermodal environment to ensure an efficient, competitive and reliable SSS operation. It is hoped that this review of literature relating to studies done on SSS in Europe would be able to trigger further research on SSS particularly in the ASEAN region. Among the areas to be explored are to evaluate the suitability of the determinants that have been identified in the European SSS experience to prospective SSS routes within ASEAN Researchers may also explore the existence of other determinants that could hinder or promote the success of a SSS undertaking that may be peculiar to the ASEAN sub-region only.

\section{Acknowledgements}

The author would like to extend his appreciation to Universiti Kuala Lumpur for the research grant provided under the Short Term Research Grant Scheme; the Malaysian Institute of Transport, MARA University of Technology for providing a conducive environment to conduct this research; and anonymous reviewers for their constructive comments on the earlier draft.

\section{References}

Arof, A. M. (2013). The challenges in the development of a feasible Short Sea Shipping in BIMP-EAGA sub-region. Marine Frontier, 4(2), 32-43.

Arof, A. M., \& Nair, R. (2014, October 21). Key factors for a feasible Ro-Ro Short Sea Shipping in BIMP-EAGA sub-region. Proceedings of the $1^{\text {st }}$ International Maritime Conference (pp 161-178). Labuan, Malaysia, Universiti Malaysia Sabah.

Asian Development Bank - ADB. (2010). Bridges across Oceans: Initial Impact Assessment of the Philippines Nautical Highway System and Lessons for Southeast Asia. ADB and Asia Foundation.

Asia-Pacific Economic Cooperation (APEC). (2007). Short Sea Shipping Study: A Report on Successful SSS Models that can improve Ports' Efficiency and Security while reducing Congestion, Fuel costs, and Pollution. Singapore, APEC Transportation Working Group \& Inha University.

Association of Southeast Asian Nations. (2011). Master Plan on ASEAN Connectivity. Jakarta, Indonesia. ASEAN Secretariat.

Association of Southeast Asian Nations. (2014). Intra- and Extra-ASEAN Trade 2013. Retrieved from http://www.asean.org/images/2015/January/external_trade_statistics/table18_as_of_04Dec14.pdf

Baindur, D., \& Viegas, J. (2011). Challenges to implementing motorways of the sea concept - lessons from the past. Maritime Policy \& Management, 38(7), 673-690. http://dx.doi.org/10.1080/03088839.2011.625990 
Baird, A. J. (2007). The economics of Motorways of the Sea. Maritime Policy \& Management, 34(4), 287-310. http://dx.doi.org/10.1080/03088830701538976

Balduini, G. (1982, April 1-2). Italy in Short-sea Shipping in the economy of Inland Transport in Europe: A Report of the Sixth Roundtable in Transport Economic (pp. 37-65). Held in Gothernburg. Washington D.C, OECD Publication and Information Centre.

Becker, J. F. F., Burgess, A., \& Henstra, D. A. (2004). No need for speed in Short Sea Shipping. Maritime Economics \& Logistics, 6, 236-251. http://dx.doi.org/10.1057/palgrave.mel.9100111

Brooks, M. R., \& Frost, J. D. (2004). Short sea shipping: a Canadian perspective. Maritime Policy \& Management, 31(4), 393-407. http://dx.doi.org/10.1080/0308883042000304881

Douet, M., \& Cappuccilli, J. F. (2011). A review of Short Sea Shipping policy in the European Union. Journal of Transport Geography, 19, 968-976. http://dx.doi.org/10.1016/j.jtrangeo.2011.03.001

European Commission. (1999). The Development of Short Sea Shipping in Europe: A Dynamic Alternative in a Sustainable Transport Chain. Second Two-yearly Progress Report, A communication from the Commission to the European Parliament, the Council, the Economic and Social Committee and the Committee of the Regions.

European Commission. (2001). White Paper - European Transport Policy for 2010: time to decide, COM (2001) 370 final, Brussels.

European Commission. (2007). Report on the Motorways of the Sea. State of Play and Consultation, SEC (2007) 1367, Brussels.

Garcia-Menendez, L., \& Feo-Valero, M. (2009). European Common Transport Policy and Short-Sea Shipping: Empirical Evidence Based on Modal Choice Models, Transport Reviews, 29(2), 239-259. http://dx.doi.org/10.1080/01441640802357192

Grosso, M., Lynce, A.-R., Silla, A., \& Vaggelas, G. K. (2009). Short Sea Shipping, Intermodality and Parameters Influencing Pricing Policies in the Mediterranean Region. Proceedings of First International Conference on Prospects for research in Transport and Logistics (pp. 291-298). Istanbul, Dogus University Publications.

Kennedy, S. D. (2008). Short Sea Shipping in the United States - The New Marine Highways. Tulane Maritime Law Journal, 33(203), 203-227. Louisiana, Tulane University.

Medda, F., \& Trujillo, L. (2010). Short-sea Shipping: An analysis of its determinant. Maritime Policy \& Management, 37(3), 285-303. http://dx.doi.org/10.1080/03088831003700678

Musso, E., \& Marchese, U. (2002). Economics of Short Sea Shipping. In C. T. Grammenos (Ed.), The Handbook of Maritime Economics \& Business (pp. 280-304). London: LLP.

Ng, A. K. Y. (2009). Competitiveness of short sea shipping and the role of port: the case of North Europe. Maritime Policy \& Management, 36(4), 337-352. http://dx.doi.org/10.1080/03088830903056983

Paixao, A. C., \& Marlow, P. B. (2001). A Review of the European Union Shipping Policy. Maritime Policy \& Management, 28(2), 187-198. http://dx.doi.org/10.1080/03088830118389

Paixao, A. C., \& Marlow, P. B. (2002). Strengths and weaknesses of short sea shipping. Marine Policy, 26, 167-178. Pergamon/Elsevier Science.

Paixao-Casaca, A. C., \& Marlow, P. B. (2005). The Competitiveness of Short Sea Shipping in Multimodal Logistics Supply Chains: Service Attributes. Maritime Policy \& Management, 32(4), 363-382. http://dx.doi.org/10.1080/03088830500301469

Paixao-Casaca, A. C., \& Marlow, P. B. (2007). The Impact of the Trans-European Transport Networks on the Development of Short Sea Shipping. Maritime Economics and Logistics, 9, 302-323. http://dx.doi.org/1479-2913-07.

Perakis, A., \& Denisis, A. (2008). A survey of short sea shipping and its prospects in the USA. Maritime Policy \& Management, 35(6), 591-614. http://dx.doi.org/10.1080/03088830802469501

Saldanha, J., \& Gray, R. (2002). The potential of British coastal shipping in a multimodal chain. Maritime Policy \& Management, 29(1), 77-92. http://dx.doi.org/10.1080/03088830110067339

Sambracos, E., \& Maniati, M. (2012). Competitiveness Between Short Sea Shipping and Road Freight Transport in Mainland Port Connections, the Case of two Greek Ports. Maritime Policy \& Management, 39(34), 321-337. http://dx.doi.org/10.1080/03088839.2012.671545 
Stopford, M. (2009). Maritime Economics (3rd ed.). London. Routledge.

Suarez-Aleman, A., Trujillo, L., \& Cullinane, K. P. B. (2014). Time at port in short sea shipping: When timing is crucial. Maritime Economics \& Logistics, 16(4), 399-417. http://dx.doi.org/10.1057/mel.2014.5.

Tapaninem, U., Sundberg, P., \& Posti, A. (2012, April 2-3). Short Sea Shipping in the Gulf of Finland - Case Helsinki-Talinn. Paper presented at Short Sea Shipping 2012 Conference, Lisbon.

Transport Canada. (2006). Making Connection. Shortsea Shipping in Canada. Canada, Department of Transport.

Trujillo, L., Medda, F., \& Gonzalez, M. M. (2011). An analysis of short sea shipping as an alternative to freight transport. In K. Cullinane (Ed.), International handbook of Maritime Economics (pp. 284-300). Cheltenham, England. Edward Elgar.

Woxenius, J. (2012). Flexibility Vs. Specialisation in Ro-Ro Shipping in the South Baltic Sea. Transport, 27(3), 250-262. Vilnius Gediminas Technical University (VGTU) Press Technika.

Yonge, M., \& Henesey, L. (2005). A Decision Tool for Identifying the Prospects and Opportunities for Short Sea Shipping. A study commissioned by the Canevaral Port Authority.

\section{Copyrights}

Copyright for this article is retained by the author(s), with first publication rights granted to the journal.

This is an open-access article distributed under the terms and conditions of the Creative Commons Attribution license (http://creativecommons.org/licenses/by/3.0/). 